\title{
JCOM \\ Science and technology for the people? On the framing of innovation in policy discourses in India and in EU
}

\section{Anwesha Chakraborty and Rita Giuffredi}

Abstract

Keywords

DOI
In 2010 both India and Europe launched new strategies focused on innovation, for economic growth and for addressing societal challenges: the Decade of Innovation from the Indian Government and the Innovation Union from the European Union. This piqued our interest in investigating how these two political entities have envisioned the concept of innovation, particularly in studying and comparing how they have focused on people, both as final beneficiaries (and thus principal legitimisers) of policy actions, and as actors themselves in the innovation process. Per contra we found, in institutional documents, very different descriptions of how to adequately realise citizens' involvement, spanning from the abiding reference to people's inclusion in the Indian case to the varied discourses on public engagement in EU, down to the passive role accorded to citizens in some Expert Groups reports. The comparison between the understandings of innovation (and innovators) in the two contexts can enlarge and refine the argumentative and metaphoric repertoire of science communicators. Further, it can form the basis of a mature and shared debate on the role that knowledge production and innovation policies can and should play in the public governance of science and technology.

Participation and science governance; Representations of science and technology; Science and policy-making

https://doi.org/10.22323/2.18030205

Submitted: 16th July 2018

Accepted: 30th April 2019

Published: 14th June 2019

In 2010 both India and Europe launched new strategies for economic growth and for addressing societal challenges focused on innovation: the Decade of Innovation from the Indian Government and the Innovation Union ${ }^{1}$ from the European Union. This piqued our interest in investigating how these two political entities have envisioned the concept of innovation, particularly in studying and comparing how they have focused on people, both as final beneficiaries (and thus principal legitimisers) of policy actions, and as actors themselves in the innovation process. Such a reading is particularly useful now that Horizon Europe, the forthcoming EU

\footnotetext{
${ }^{1}$ A flagship initiative of the Europe 2020 growth strategy.
} 
Framework Programme, is taking shape, with almost ten years passed in between the two Programmes (ie. Horizon 2020 and Horizon Europe).

Our perspective positions this paper among the studies of conceptual frameworks (and of their many iterations such as imaginaries, discourses, narratives) essentially related to techno-science. Specifically, we have based our reading of policies on the approach of "conceptual frameworks" developed and used by innovation scholar Godin [2009], which, in contrast with rational-choice or instrumental rationality analyses, understands policy as «a process of argumentation». Following earlier elaborations [Fischer and Forester, 1993; Schön and Rein, 1994], he defines a "conceptual framework", or "frame", as "an argument or discourse that acts as an organizing principle to give meaning to a socioeconomic situation and answers to a series of analytical and policy questions» [Godin, 2009, p. 2]. Frameworks are often constructed as narratives, which possess a time dimension and imply a development. In this study, we also make use of other related terms: discourses, rhetoric, argumentations, imaginaries, with similar overall meaning but specific features. Referring to the analysis of the policy scholars Fischer and Gottweis [2012], the term "argumentation" points to the process by which people "seek to reach conclusions through reason» [Fischer and Gottweis, 2012, p. 9] engaging in persuasive dialogues; conversely, «rhetoric» refers to the linguistic and communicative methods of argumentation, aiming at constructing a "particular representation of reality» focused on the audience, instead than on the object itself [Fischer and Gottweis, 2012, p. 10]. A «discourse» is a more general concept: it is a set of ideas, concepts and categories which we draw upon when trying to persuade others. Such a "pool" of reference, then, includes and circumscribes «the views that can be legitimately accepted as knowledge, and constitutes the actors taken to be the agents of knowledge» [Fischer and Gottweis, 2012, p. 11]. A discourse acknowledges the shared set of values and «supplies society with basic stories and narratives that serve as modes of behaviour» [Fischer and Gottweis, 2012, p. 11]. For the definition of "imaginaries", finally, we use STS scholars Jasanoff's and Kim's description of socio-technical imaginaries as collectively shared and performed visions where techno-science plays a central role in envisioning the future [Jasanoff and Kim, 2015].

Our analysis is intertwined on one side with science policy studies and on the other with science communication, since we specifically study S\&T-driven innovation policy discourses. Policy discourses by themselves are a peculiar form of communicating science, a most neglected one in recent academic literature [Nowotny, 2014]. Moreover, the high-level policy discourses we examine notably influence numerous other forms of science communication in terms of themes, arguments and acceptable legitimations. In addition to this, since we study the representations of citizens as final beneficiaries of public research funding, our study intends to throw light on the understanding of the science-public interface. Furthermore, these frameworks have important consequences on the understanding of scientists' /innovators' role in contemporary knowledge societies.

Analysing Indian and EU documents we found out that, although the master narrative is common - stemming from an analogous, globally shared, economic orientation for S\&T-driven innovation - the description and implementation of innovation policies is peculiar to each political entity, especially for what concerns its non-strictly economic characterization. The purpose here has been to investigate 
how the people-centred, society- or development-oriented descriptions of innovation are depicted in public documents and communicated to the concerned actors, be they decision-makers, stakeholders or citizens at large. From our close reading of the policy documents and reports, we came across different understandings and attitudes towards civic engagement in innovation processes, which shall be discussed in detail in the next sections.

\section{Why EU and India?}

We have chosen to compare India and EU because, notwithstanding their clear differences, ${ }^{2}$ these are two major economic and technological powers with a history of scientific collaboration ${ }^{3}$ - Indian academics, scientists and research institutions participate in several Horizon 2020 projects $^{4}$ - and due to their shared interest in claiming the present decade as the one of innovation. In a EU Commission document, which reviews the S\&T cooperation between EU and India, independent experts Basile and Réigner [2012] wrote: «With the adoption of the European Research Area Vision 2020 - and the key role ascribed to innovation in the Europe 2020 Strategy - and with the launch of India's decade of innovation, EU-India relations in S\&T have become strategic, both for the EU and India» [Basile and Réigner, 2012, p. 1]. Both political entities have seen their technological and economic apparatuses develop in the same post-war period; both, in different ways, are collections of different states - the European nations and the various linguistic states which acceded to the Indian Union after the British rule. The European project was from its foundation an effort of coordination in economic terms, with the perspective of realizing a social and political union; in this process, science and technology were motors for integration [Guzzetti, 1995; Felt, Fochler and Winkler, 2010]. It would not be too far-fetched to argue that the formation of the Union of India post-independence (ie. 1947) shares a similar historical trajectory with the accession of the different states to the union ${ }^{5}$ with a strong focus on science and technology for building a postcolonial nation - «To develop scientific temper, humanism and the spirit of inquiry and reform» is one of the fundamental duties, according to the Indian Constitution.

In policy studies literature, it is well established that the study of public policy should be comparative [Wilder, 2017; Dodds, 2012; Heidenheimer, Heclo and Adams, 1975]. The attempt here is to draw reasonable conclusions on diverse technopolitical cultures [Felt, Fochler and Winkler, 2010] with examples of two

\footnotetext{
${ }^{2}$ We just mention here the most obvious one: the economic situations and outlooks. As per 2017 World Bank data, India is the sixth largest economy in the world (in terms of nominal GDP), whose prospects of growth are positive due to its young population, and yet the country requires a robust infrastructure for inclusive growth, and an innovation ecosystem which can involve many actors of its billion plus population. On the other hand, Europe has entered into a period of acute crisis, summing to the previous decades-long feeling of economic lag, and has to face the problem of an aging population. Nevertheless, the EU continues to be the second largest economy (as per IMF figures from 2016, the European Union is the second largest economy in the world, including data from the United Kingdom), and with its Horizon 2020 programme, seeks to maintain its competitive advantage.

${ }^{3}$ See http:/ / eeas.europa.eu/archives/delegations/india/eu_india/research_innovation/ index_en.htm.

${ }^{4}$ See http:/ / ec.europa.eu/research/participants/data/ref/h2020/other/hi/h2020_localsupp_ india_en.pdf.

${ }^{5}$ Article 1 of the Constitution of India mentions that India shall be a Union of States.
} 
major economies: we want to study how technologies are interwoven in society and to explore nationally distinct ways in which technoscience is entangled with cultural norms and values. "Comparison across social and political structures», in the words of Jasanoff and Kim, «not only helps to identify the content and contours of sociotechnical imaginaries but also avoids the intellectual trap of taking as universal epistemic and ethical assumptions that turn out, on investigation, to be situated and particular» [Jasanoff and Kim, 2015, p. 24]. At the same time, the understanding of culture-specificity doesn't necessarily prevent fruitful exchange of political ideas and can be a starting point for a public debate on various understandings of innovation. Political narratives, like the discourse on innovation, have far-reaching consequences on the shaping of political entities themselves, on how they conceive their identity and on how they plan to modify it. Political imaginaries are able in a dialectic (always non-deterministic) interplay to influence socio-political changes or to sustain institutional stability and self-conservation - e.g. identifying relevant issues, legitimizing actors and generally circumscribing political argumentation [Jasanoff and Kim, 2015; Fischer and Gottweis, 2012]. Shared imaginaries or narratives are particularly visible in policy documents, where they are invoked to frame relevant issues and ultimately legitimise policy action, based on a specific idea of desirable future. Furthermore, comparing EU and India allows to extend our gaze beyond North America and Europe: non-western-centred points of view are lacking in scientific literature on policy-making [Wilder, 2017]. They are very useful to understand, through comparison, strongly culture-dependent ideas like innovation and knowledge policies, and the shape that citizens' participation takes in different contexts.

In the last couple of decades, citizen participation has gained major academic attention in the fields of public understanding of science and science communication, which have been critical of the deficit model of the 1980s that casts publics as lacking in scientific knowledge [Irwin and Wynne, 1996]. Irwin [2014] notes that the House of Lords report on 'science and society' [House of Lords, 2000], which brought on discussions on the 'dialogue model', triggered multiple European Commission activities culminating in concepts like Responsible Research and Innovation and societal issues which were to be addressed through various national engagement initiatives. Davies et al. [2009] have argued that the importance of dialogue events in informal non-policy settings such as science cafes or museums need to be studied as effective instances of democratisation of science. Issues of citizen engagement on matters like climate change, energy, GMOs have found increased expression in the literature (see for example, the 2016 edited volume of Chilvers and Kearnes which carries articles on public participation, citizen engagement and co-production of knowledge in the making of science, technology and innovation within democratic, primarily global north, frameworks). At the same time, scholars from non-European contexts (and from various disciplinary fields) have been mentioning the need to incorporate 'lay' or 'local' knowledges and perspectives under the rubric of scientific and innovative knowledge; and have discussed instances of community involvement in regions such as New Zealand, Australia and India [Goven, 2006; Schibeci and Harwood, 2007; Gupta, 2013].

«Innovation» is currently the mainstream keyword in economic strategies for growth worldwide as well as in Europe: STS scholars Pfotenhauer and Jasanoff describe it as a «leitmotif of policy-making and institution-building around the 
globe» [Pfotenhauer and Jasanoff, 2017, p. 784]. A discussion of the ideas of innovation, which both political entities proclaim as a crucial objective for their growth, will provide an insight into how the concept has deep historical, socio-cultural, value-related roots and the degree by which it is able to shape policy decisions and visions of $S \& T$ related future. It is important to mention here that the documents we have discussed are results of recent policy positions on innovation with reference to the two decade-long frameworks (see Table 1). This short essay does not purport to comment on science and technology policies of India and EU in general, nor on their more recent and still under development evolutions; rather it seeks to understand what are the major discourses around innovation, how it is imagined and narrated in the publicly available policy documents pertaining to the two decade-long periods and what the implications are on the actors and on the understanding of the process of knowledge production.

\section{Methodology}

To explore the European and Indian approaches to people-centred innovation we have analysed a set of policy documents and public reports on S\&T-driven innovation policies. First, we have identified the most influential institutional bodies which draft the policies, i.e. realise the preliminary work of collecting, choosing and developing ideas and imaginaries. Indeed, these agenda-setting and policy formation stages are, among the different phases of policy-making, the most important moments with regards to our aim: conceptual frameworks and narratives are mainly established in this preliminary phase, while the following stages are usually negotiation-intense and are prominently relevant for interests- or rational choice-based analyses [Andrée, 2009]. For this preliminary study, we have decided to focus on the conceptual frameworks of innovation, with minor references to the (power or interests) positions of the people who wrote or discussed the documents: their institutional or personal viewpoints, influences and beliefs, which are important to investigate, but are out of the scope of our comparison of narratives. We have, however, taken into account these contributions when dealing with end-of-process documents, which naturally retain the footprints of all the previous stages.

For what concerns the EU, the political preparation stage is realised by the Commission, the body which has the right of legislative initiative in the European institutional structure. ${ }^{6}$ It publishes mainly two types of documents: policy preparation documents and experts' reports. The first, including communications, working documents, consultations outcomes green and white papers, are authored by internal officers and normally only mention the responsible office; the second are requested to ad hoc high-profile experts' groups on relevant themes in order to

\footnotetext{
${ }^{6}$ The European Commission retains the «right of initiative» for new legislative proposals — even if it is often asked to develop projects along the political lines established by the Council; - it practically organizes the collection of the information base and realizes the draft documents to be debated in the Council and in the Parliament. The Commission's powers are variable in relation with the policy domain: depending on the issue at stake, hence, the Commission can play the role of a real executive agency - e.g. in competition policies - or of the "agenda-setter", proposing new legislations; it can negotiate on behalf of the EU - e.g. for what concerns the external economic relations - or it can be responsible of comparing and coordinating national policies, and of building extensive cross-EU networks to establish technical reference standards; in intergovernmental areas it acts as a simple observer.
} 
establish the state of the art or to evaluate specific policy processes or initiatives. These experts' reports represent a notable fraction of the Commission's publicly available publications, and some of them have proved to be rather influential on the elaboration of official political positions. In addition to the Commission's publications, the Framework Programmes (FPs) and the European Research Council (ERC) establishing acts have proven to be particularly revealing of the EU science policy conceptual frameworks' features. These are (lengthy and comprehensive) legal documents representing the final outcome of the policy-making process and are authored, as for the FPs, jointly by the European Parliament and the Council, ${ }^{7}$ as for the ERC by the European Commission.

In case of India, to understand how the Decade of Innovation has found institutional and policy-level expressions, we have chosen the most recent national document titled Science, Technology and Innovation Policy of 2013 (authored by the Ministry of Science and Technology, Government of India) alongside recent annual reports of two key public institutions, the National Innovation Council and the National Innovation Foundation. The first was created by the then central government as a think tank to chalk out the roadmap for the 'Decade of Innovation'. While it has become defunct, its policy proposals are crucial to understand the official narrative of the Decade of Innovation. The second institution, which functions under the aegis of the Department of Science and Technology, Government of India, predates the announcement of the policy but has an active role in promoting its mandate.

For both political entities, we have consulted information on the features of conceptual frameworks as notably expressed in public communication documents (annual reports, videos, websites, leaflets) as well, where the effort of summarising and effectively communicating the policies often highlights their most relevant traits. Further, we have considered scholarly debates around the policy frameworks, (especially works of researchers who contribute to policies) which provide the context in which these policies are framed.

The EU documents were chosen through a snowball sampling methodology: beginning with the most recent, we traced back the history of references in the analysed documents, considering the frequency or emphasis of the citations as an indicator of relevance, until we built a corpus coherent and cohesive enough for our analysis. ${ }^{8}$ The prime criterion for the choice, hence, is the importance ascribed to policy documents inside the documents themselves: in other words, we are reasonably sure that the considered documents have had an impact on the policies - or, at least, that they were rhetorically evoked as important references by following documents. In case of India, a thorough Google search revealed the main documents and institutions engaged in the promotion of the decade-long strategy. As documentation on the policy is scarce, we have also consulted reports prepared by Indian policy scholars for joint Indo-European projects under Horizon 2020, which discuss India's innovation strategies with reference to the framework.

\footnotetext{
${ }^{7}$ With the exception of those establishing the First (1983), Second (1987) and Third (1990) Framework Programmes, which were authored by the Council only.

${ }^{8}$ For example, the Sapir, Strauss-Kahn, Kok and Aho reports were cited as notably influential in the development of the Lisbon strategy by the account on the design of the 7th Framework Programme drafted by the Commission research policy officers [Muldur et al., 2006, pp. 76-77], and references appear in numerous other documents.
} 
For this study, we chose to perform document analysis, as documents of different types are useful for the researcher to study a research problem in depth and to develop new understandings and fresh insights [Merriam, 1988; Bowen, 2009]. While document analysis is often used in conjunction with other qualitative research methods such as interviews, participant observation, field visits, this study involved solely the analysis of different types of documents: including official policy documents, analytical policy research reports and institutional reports, as document analysis can be used as a 'stand-alone method' [Bowen, 2009, p. 29] for qualitative research. This paper seeks to comment on the various discourses of innovation in EU and Indian policies through documental evidence, but it also recognises the importance of further investigation through the employment of other methods, such as but not limited to, semi-structured interviews with policy makers (and for a large scale study, with members of the public), questionnaires, field visits and participant observation during the policy-making process. The sampled documents were chosen to explore a range of opinions and different representations of an issue [Gaskell, 2000], in this case, innovation. While performing close reading, involving re-reading and review of the documents, we specifically looked for words such as 'innovation', 'responsible', 'public', 'people', to understand how the role of the public is discussed in them, and examined the text around these words to appraise and synthesise the data as a part of the analytical process [Bowen, 2009]. We used the inductive approach to interpret the rhetoric about S\&T-driven innovation and public engagement, post the examination of themes such as responsible/grassroots/local innovation which emerged from the documents.

Europe as an Innovation Union
In 2010 the European Union decided to launch the «Europe 2020» growth strategy and made «Innovation Union» one of its flagship initiatives. Knowledge production activities were positioned at the heart of the strategy [European Commission, 2010a], and the eighth Framework Programme for research funding, Horizon 2020 (2014-2020), was conceived as firmly anchored to the concept of innovation from its very denomination: Horizon 2020 is indeed the first «Framework Programme for Research and Innovation», while the previous were aimed at «research, technological development and demonstration activities». According to the Commission proposal, the Programme is geared at ensuring that «innovative ideas can be turned into products and services» [European Commission, 2010b, p. 5] and it is designed as the «key tool in implementing the Innovation Union Flagship Initiative» [European Commission, 2011, p. 2].

The concept of «innovation» in European discourses is, on one side, portrayed emphasizing its consequences on «the individual and society» [Commission of the European Communities, 1995, p. 1]:

innovation is taken as being a synonym for the successful production, assimilation and exploitation of novelty in the economic and social spheres. It offers new solutions to problems and thus makes it possible to meet the needs of both the individual and society.

In parallel, also under the influence of the OECD work on the measurement of scientific, technical and innovation activities (with the publication of the Frascati, 
Oslo and related manuals) [Godin, 2009; e.g. OECD, 1963; OECD, 1993; OECD, 2015; OECD and Eurostat, 1996; OECD and Eurostat, 2005], the European documents adopted a representation of science as "research accounting" and developed a stricter economic definition of innovation [Commission of the European Communities, 1995, p. 1]:

the renewal and enlargement of the range of products and services and the associated markets; the establishment of new methods of production, supply and distribution; the introduction of changes in management, work organisation, and the working conditions and skills of the workforce.

This double-focused understanding of the policies of knowledge can be recognized as an abiding feature of the European approach, thereby also creating diverse imaginaries and narratives on innovation and innovators.

The predominant Communitarian frame for S\&T policy was historically the utilitarian, economy-oriented "science for growth" discourse, also as a consequence of its long history of economic community - EU acquired the political dimension only with the Maastricht Treaty in 1993. During the '80s, technological development, aiming at improving European industrial competitiveness, was the principal objective of research policy; this frame easily shifted in the '90s towards the new innovation paradigm, centred on a more innovation-friendly economic environment and on a scientific policy fostering research activities closer to marketable applications [Borrás, 2000; Sanz Menéndez and Borrás, 2000; Caracostas and Muldur, 1998; Guzzetti, 1995].

Knowledge policies moved high in the European agenda around the turn of the Millennium with the Lisbon Strategy, developed around the aim of building a «Europe of knowledge», whose dimensions were initially described as economic as well as cultural, social, citizenship-oriented [Sorbonne Declaration, 1998; Commission of the European Communities, 1997]. However, the use in political discourses of the «Europe of knowledge» conceptual framework evolved rapidly in the first years post-2000, losing ground in favour of the new political objective of the "Innovation Union» [Commission of the European Communities, 2003], paired with a consequent shift from wider political and social objectives towards a more pronounced economic orientation [Sapir, A. et al., 2003; Kok, W. et al., 2004; Aho et al., 2006; Cerroni and Giuffredi, 2015; Giuffredi, 2016].

In the current strategy, innovation is framed as the key concept to address a great variety of issues, a real 'champion' of problem-solving [European Commission, 2010b, p. 6]:

As public deficits are reined in to repair public finances and as our labour force begins to shrink, what will be the basis for Europe's future competitiveness? How will we create new growth and jobs? How will we get Europe's economy back on track?

How will we tackle growing societal challenges like climate change, energy supply, the scarcity of resources and the impact of demographic changes? How will we improve health and security and sustainably provide water and high-quality, affordable food?

The only answer is innovation, which is at the core of the Europe 2020 Strategy (...). It aims to (...) ensure that innovative ideas can be turned into products and services that create growth and jobs. 
EU makes an emphatic point in identifying innovation as the unique possible path to both regaining economic prominence and improving people's quality of life through solving the listed pressing challenges, mainly pertaining to environment, European demography and society at large. Innovation indeed is understood as the ability of transforming knowledge (from research) into marketable products (suitable for boosting economic growth), while simultaneously tackling «growing societal challenges». Economic and social objectives, historically conceived as coupled in the "EU model", appear related, in a linear, mostly automatic, process, where innovation plays the role of a bridging concept linking economic growth to the increase in quality of life, through the diffusion and use of the products of research.

\section{People's engagement à l'européenne: RRI, Societal Challenges and inclusive processes}

Even in the context of a clear prominence of the contribution to economy, European discourses, as mentioned, traditionally pair economic growth and social aims, pointing at the "citizens" as the final beneficiaries of the policies, and at the positive impact on "society" as their principal legitimising factor.

In recent years, multiple instances refer to an increase in the involvement of society in S\&T-driven innovation: growth is intended to be «sustainable and inclusive», reflections on the interplay between "Science and Society» and on the concept of «Responsible Research and Innovation» (RRI) have developed, and the H2020 lines of funding have been articulated, for the first time, around Societal Challenges in place of the traditional discipline-based distribution.

RRI's origins can be traced back to the last two decades of research on the interplay of science and society, a topic which was included in the Framework Programmes for the first time around the turn of the millennium. In the same period of the conceptualization of the Europe of knowledge, indeed, a new awareness grew in Europe around the understanding and practice of positive interactions between the scientific and societal actors. This was also a consequence of a series of science-related issues, whose management by the authorities contributed to undermine the public trust in science (or at least in some specific branches and uses of it; e.g. the Creutzfeldt-Jakob disease management or the regulation of the uses of GMO in agriculture) [Jasanoff, 2005; Wynne, B. et al., 2007].

The issue of «Science and Society» experienced a significant evolution in the following years, both in definitions and understanding. It was first renamed "Science in Society», to underline the non-separability of the two realms and the nature of knowledge of being co-produced by both scientists and societal actors [Stirling, 2006]. It was included in H2020 under the denomination of «Science with and for society», the further shift in prepositions being aimed at highlighting the commitment to orientate scientific research towards social aims [Owen, Macnaghten and Stilgoe, 2012]. The main focuses of the "science and society" approach whatever the prepositions - have traditionally been the ethical concerns on research activities and the need to engage citizens in the governance of science.

In the Responsible Research and Innovation framework, developed by scholars and Commission officers in the years preceding the launch of Horizon 2020 [Von 
Schomberg, 2013; see also Stilgoe, Owen and Macnaghten, 2013; Owen, Stilgoe et al., 2013; Owen, 2014], these two focuses - ethics and engagement - appear juxtaposed with gender equality, scientific education and open access, all grouped under the umbrella concept of governance [European Commission, 2015].

The label of «Responsible Research and Innovation» (RRI) refers to [Von Schomberg, 2013, p. 19]:

a transparent, interactive process by which societal actors and innovators become mutually responsive to each other with a view to the (ethical) acceptability, sustainability and societal desirability of the innovation process and its marketable products (in order to allow a proper embedding of scientific and technological advances in our society).

A precise conceptualization of RRI is still ongoing. In the academic debate (reflected in experts' reports), it is set in broad-enough terms to be interpreted with different anchor points; although these scholarly perspectives don't necessarily reflect the Commission's vision of RRI, they show how the concept is subject, in the public debate, to very diverse framings. For example, a 2011 report on Responsible Research and Innovation developed the concept mainly around «the consistent, ongoing involvement of society, from the beginning to the end of the innovation process» [Sutcliffe, 2011, p. 3], while a 2013 Expert Group report, e.g., devoted considerable space to the desirability of RRI in economic terms [van den Hoven, J. (chair) et al., 2013]. The debate about the 'responsibility' dimension of research and innovation activities shows a diverse and evolving landscape, incorporating visions leaning towards different objectives. These include the more speculative level of defining clear and comprehensive conceptual bases [see van den Hoven, J. (chair) et al., 2013; Von Schomberg, 2013]; the democratic argument advocating the involvement of the citizens' deliberation about values in the policy-making process [e.g. Sutcliffe, 2011]; the pragmatic approach of building an online repository of RRI experiences, to act as an operative reference for all the stakeholders [RRI tools, 2014].

As for the communication products, RRI in the Commission's website, videos and leaflets is systematically framed with the metaphor of the «alignment» of R\&I with the «values, needs and expectations of European society» [European Commission, 2015; European Commission, 2012; European Commission, 2014]:

Responsible Research and Innovation (RRI) implies that societal actors (researchers, citizens, policy makers, business, third sector organisations, etc.) work together during the whole research and innovation process in order to better align both the process and its outcomes with the values, needs and expectations of society.

This approach reflects the effort of considering people's concerns on the ethical aspects of research as well as their position on the orientation of science. However, the «alignment» metaphor conveys the false perception that two secluded realms exist - the one where the scientific process takes place and the other where people experience social relations and express positions and concerns. Moreover, the emphasis on «values, needs and expectations» appears to downgrade the capacity of social actors to contribute as real knowledge co-producers and partially 
overrides the complexity of the democratic process of political decision-making on scientific issues, which should not only involve taking into account (alleged) societal values but should also include the citizenry at large in having a voice along the process itself.

In media and policy documents RRI appears very often paired with the concept of Societal Challenges, the one presented as the European 'ability' to solve the second, while at the same time ensuring research efficiency [European Commission, 2012; European Commission, 2015; van den Hoven, J. (chair) et al., 2013]. The emphasis on the definition of "Grand Challenges" instead of abstract political strategies has particularly grown in recent years, both globally and in Europe. In the EU, this rhetoric gradually emerged during the years of the Lisbon Strategy as an alternative narrative to competitiveness for research activities [Ulnicane, 2016].

Although the recommendation of focussing R\&D programming on the identification of complex challenges was occurring in EU science policy discourses since the turn of the millennium [e.g.: Strauss-Kahn, D. et al., 2004; Muldur et al., 2006; Caracostas and Muldur, 1998], it was retained and promoted in subsequent EU documents [Commission of the European Communities, 2007; Georghiou, L. et al., 2008; The Lund Declaration, 2009], with new purposes: as instruments to facilitate the involvement of a wider spectrum of stakeholders in the research agenda definition process, as a political answer to societal pressures, and as instruments «to capture political and public imagination, create widespread interest through scientific and business communities and NGOs and inspire younger people» [Georghiou, L. et al., 2008, p. 8].

The concept of Grand/Societal Challenges in the European discourses, used as a strategy to reorganize resources for R\&D and to improve research impact, wavers between a democratic understanding, favouring the inclusion of citizens' concerns in the R\&D agenda, and an instrumental one, in which it is used as a rhetorical tool to promote research and obtain public support for science. Unavoidably, the challenge-based approach shifts the focus from an inclusive agenda-setting process to the emphasis on problem-solving. The R\&D community is coherently, according to this frame, requested to contribute to society with techno-scientific fixes, rather than with political, social, ethical ideas, to the solution of the challenges.

In European science policy discourses a critical point is represented, therefore, by the degree of inclusion in knowledge production processes of the citizens, described from case to case also as «users», «consumers», «workers», «taxpayers»: 9 their role indeed ranges from a passive characterization, involved only at the end of the process to comply to previously set orientations, to the position of real knowledge co-producers, carriers of relevant values and involved throughout the whole process since the first agenda-setting stages. In innovation discourses, the knowledge production chain is described to span «from blue sky research to market uptake» [European Commission, 2010b]: citizens are not usually considered central actors of the innovation process. The most frequently mentioned actors are

\footnotetext{
${ }^{9} \mathrm{Cf}$. for example the terms, referring to the citizens, included in the Framework Programmes establishing acts - the legal acts by which the EU enforces the research funding programmes [e.g. European Parliament and Council of the European Union, 2006; European Parliament and Council of the European Union, 2013; European Parliament and Council of the European Union, 2002, only to mention the last three Programmes].
} 
researchers, companies and especially entrepreneurs. The entrepreneurial category is represented not only as the target beneficiary of support and funding, but also as the object of cultural promotion, centred on fostering «entrepreneurial education» and the development of «more positive European attitudes and culture towards entrepreneurship and risk taking» and on the realization of a real «cultural shift which celebrates innovation» [European Commission, 2010b; EC, EACEA and Eurydice, 2016; European Parliament and Council of the European Union, 2013; Aho et al., 2006].

In the next section, we examine the Indian policy position regarding who are the actors in the innovation landscape. As a recent report suggests, while RRI is a new concept in India and the specific notions of responsibility that it promotes are not present in Indian science policies, the fact that science and technology-led innovation is envisioned for societal and national development shows that the idea of responsibility is not absent [Srinivas, Kumar and Pandey, 2018]. This feature of Indian science policy documents also gives rise to a different set of actors.

The Indian decade of innovation
Any discussion on science and technology policies in independent India requires a quick comment on the purpose of such policies. Indian historians agree that science and technology were accorded prime position in framing the vision of a self-reliant postcolonial state [Abraham, 2006]. STS scholar T. Jayaraman furthermore traces this phenomenon back to the colonial era in the rhetoric of the freedom movement, and in Jawaharlal Nehru's phrase 'scientific temper' which according to him encapsulates the imagined ethos of a new nation, where critical attitude and rational thinking would take precedence over everything else [Jayaraman, 2009]. However, while the rhetoric of self-reliance was prevalent right after independence from the early five-year planning periods which were to guide the national vision for growth and modernization [Planning commission, 2001], Jayaraman [2009] also noted that the focus on indigenous development of technology was still quite low. Technology import was prevalent, especially because the technical base and competences were inadequate to meet the needs of the society. In the decades following independence, India has made progress in certain sectors of science and technology like space launching and satellite design, software, telecommunications, atomic energy and pharmaceuticals. However, the state still lacks a robust research and development infrastructure and an innovation ecosystem [Krishna, 2016]. It is in this context that the rhetoric of the STI policy document of 2013, and the Decade of Innovation (which precedes the publication of the document) will be analysed.

The inclusion of the word 'innovation' in the Indian science and technology policy document is a recent phenomenon. The most recent science, technology and innovation policy of the Government of India, a slim 16-page document, states that:

Scientific research utilizes money to generate knowledge and, by providing solutions, innovation converts knowledge into wealth and/or value. Innovation thus implies science and technology-based solutions that are successfully deployed in the economy or the society. It has assumed centre stage in the developmental goals of nations. Paradigms of innovation have become country and context specific. India has, hitherto not accorded due importance to innovation as an instrument of policy. [Ministry of Science and Technology, Government of India, 2013, p. 2] 
It is important to note the definition of innovation - science and technology-based solutions used for the development of the economy or the society — have strong resonance with those of the European Commission. The document further explains the specific areas and sectors where innovation will play a major role, and who will be the major beneficiaries of this innovation. This is where we find the divergence, primarily because of the differences in societal challenges.

New structural mechanisms and models are needed to address the pressing challenges
of energy and environment, food and nutrition, water and sanitation, habitat,
affordable health care and skill building and unemployment. "Science, technology and
innovation for the people" is the new paradigm of the Indian STI enterprise. The
national STI system must, therefore, recognize the Indian society as its major
stakeholder. Global innovation systems tend to bypass large sections of the community.
Innovation for inclusive growth implies ensuring access, availability and affordability
of solutions to as large a section as possible. [Ministry of Science and Technology,
Government of India, 2013, p. 3, emphasis retained from the original document]

Here it is important to pause and consider the following: what does it mean to engage with the society as the major stakeholder? Does the policy envision people as active participants in creating innovation? Reading further down the line, the document provides an answer when it discusses the need to attract young students to a career in science and technology, under the sub-heading 'nourishing the roots' [p. 6]. It could be argued that it is of great interest to India with its 1,3 billion plus population, the majority of whom is under 30 years, to focus on the grassroots level to benefit from the demographic dividend that potentially arises from it. As we will see further in this analysis, other national policy frameworks (as evident from policy documents and reports of public think-tanks) expand this concept of nourishing the roots to include a bottom-up approach to innovation. However, it is important to understand that context that warrants such a strong focus on people.

The reality of research and development funding in India is one that requires immediate action. While India becomes a prosperous nation over the years, and all economic forecasts are optimistic about the country's potential to grow and be counted as a major economic power, it still has major deficits in terms of actual investments in R\&D, as the present percentage of Gross Expenditure on Research and Development (or GERD) stands at less than 1\% (around 0,95\%) of the GDP. In comparison, most developed countries spend around 2\% of their GDP. Asian giants like China, South Korea and Japan spend much more than the $2 \%$ threshold. Successive governments have repeatedly committed to increasing GERD; however, the reality continues to be the same. In case of India, the other major concern is that $70 \%$ of this $0,75 \%$ comes from public money, with the private sector contributing a mere 30\% to the national R\&D [Krishna, 2016; Ramasami, 2011]. As a 2014 OECD policy report points out, the issue of inputs to innovation therefore remains a challenge, because of very little involvement of the business sector.

The onus on being the main driver of research and innovation in the country is on the public research system which consists of laboratories under various science and technology agencies and universities which are funded primarily by public money. This, in a country like India where access to higher educational and research institutions is restricted to a select few because of multiple social and economic factors, is a major problem that requires immediate attention, as the bottom of the 
socio-economic pyramid otherwise risks being relegated to the background perennially. Jayaraman, talking about brain drain, further highlights the externalities of Indian investments in S\&T: «The higher education base for S\&T continued to be built on a base of widespread illiteracy. At the same time, several factors induced sections highly educated scientific and technological manpower resource pool to move out of India in search of opportunities. Thus some part of India's investment in S\&T higher education ended up serving other nations' requirements, particularly the United States.» [Jayaraman, 2009, p. 5] Focusing on harnessing local technical know-hows and including actors across spectrum in the innovation ecosystem is thus a necessity, as it can drive the inclusive growth agenda. The following paragraphs discuss the rhetoric of the Decade of Innovation, a policy measure launched in 2010 which resulted in concerted efforts to raise consciousness about innovation as an instrument of policy.

The declaration of the Decade of Innovation (2010 to 2020) in the end of 2010 by then President Pratibha Patil witnessed the subsequent establishment of the think tank National Innovation Council ${ }^{10}$ by the central government. This institution was founded to formulate and implement a strategy for inclusive innovation in India. On its website (which now functions as an archive of the institution), the aim is clearly stated: «The aim is to herald a mindset change and create a push at the grassroots level so that more and more people in education, business, government, NGOs, urban and rural development engaged in innovative activities are co-opted and are part of shaping the national level innovation strategy». ${ }^{11}$ It must be noted here that while this policy was formulated by the previous government, the present one which is due to remain in power until mid-2019, has endorsed and begun to implement it [Krishna, 2016]. The National Innovation Council, however, has become dysfunctional in the same period due to lack of patronage from the current central government. Nevertheless, its role as a first step towards creating a national innovation ecosystem and providing a major thrust to the discussion on grassroots innovation need to be emphasized. The parallels between the mandate of the National Innovation Council and the language of the STI policy document, and their focus on nourishing grassroots innovators, are not coincidental either.

\section{Focus on grassroots innovators}

Anil Gupta, one of the main Indian proponents of the concept of 'grassroots innovation' discusses the need to harness people's skills and knowledge. The author of the provocatively titled Grassroots Innovation: Minds on the Margin are not Marginal Minds [Gupta, 2016] has argued that resource-starved citizens should not be considered as the bottom of the knowledge and innovation pyramid. He urges that we take note of the resources in which poor people are rich and their local, rooted knowledge systems, if we aspire for a dignified developmental process [Gupta, 2013].

With this people-centric, bottom-up approach to innovation, it is not surprising then that the very definition of innovation in this context constitutes a wide variety of products, activities and applications. The National Innovation Foundation or

\footnotetext{
${ }^{10}$ See https: / / ec.europa.eu/research/iscp/pdf/policy/india_comm.pdf.

${ }^{11}$ Further information can be found at: http:/ / innovationcouncilarchive.nic.in/index.php? option=com_content\&view=article\&id=26\&Itemid=5.
} 
NIF (not to be confused with the National Innovation Council), whose establishment in 2000 precedes the present policy formulation and where Gupta also serves as a board member, is an autonomous organization under the Department of Science and Technology, Government of India, and has been at the forefront of harnessing traditional knowledge and providing rural innovators financial and institutional support to file patents and to validate the technologies so that they may be able to sell their innovation in the wider market. In the 'Technology Catalogue' page of the Foundation's website, which lists some of the grassroot innovations that the organisation has supported, one can find a list of devices/applications/products which are for everyday use and are meant to aid the livelihoods of people, especially in rural areas where agriculture is still the main avenue of income. The names of the inventors also figure prominently in these pages. Some of these examples include low cost paddy thresher, a new variety of cardamom and a device called 'tree climber'. All these are examples of technology for the people, made by the people. The NIF is interested in identifying and nurturing the creativity and the scientific temperament of people that lead them onto finding technological solutions for everyday needs, by providing them media recognition, filing patents to protect intellectual property rights and creating an ecosystem where creative ideas are funded. [National Innovation Foundation, 2015]. For example, the NIF and Small Industries Development Bank of India have launched the Micro Venture and Innovation Fund for this purpose. There are also special awards (namely, IGNITE awards) instituted for school children who come up with technological solutions for various societal challenges. Apart from locating and nurturing grassroots talents, as a part of the Decade of Innovation initiative, the NIF has also been organizing exhibitions on grassroots innovation at the President's house since 2010. More recently, these exhibitions have been a part of a larger Festival of Innovation, which is an initiative of the Office of the President of India to recognize and reward grassroots innovators. ${ }^{12}$

In sum, it can be said that innovation in the Indian context refers to the quest for inclusive development. It is also assumed that the citizens will actively partake in the developmental process. While India excels in 'frugal innovation' [OECD, 2014], a sustained facilitation of grassroots innovation and entrepreneurship is necessary so that communities from all sections of the society can be a part of economic activities generated from such efforts.

So, who are the people in innovation discourses? Some final thoughts
The attempt in this paper has been to study instances of public communication of science and technology-driven innovation where policy makers and expert groups speak to the society through publicly available documents. Public communication through policy documents has not been a major concern of science communication scholars, even if they have started to gain prominence in academic discourse. ${ }^{13}$ The paper also attempted to comment on the role of citizens in democratic knowledge societies through the analysis of their positioning — their framing - in policy discourses on innovation.

As we have seen, although sharing the focus of their respective decade-long strategies, the Indian and the European frameworks of innovation, at least for what

\footnotetext{
${ }^{12}$ The page on Festival of Innovation can be found here: http:/ / nif.org.in/foin-2017.

${ }^{13}$ Case in point, e.g., is the September 2018 issue of JCOM which carried a set of commentaries on RRI.
} 
concerns rhetorical formulations, show several distinct features which are noteworthy as they present two understandings of the same concept developing in different contexts with specific features and serving different social purposes. This acknowledgment of contextual specificity opens up the opportunity of debating the features of innovation, instead of downgrading it to a neutral, economic or technical issue which only needs to be implemented.

We have noticed that both political entities define innovation as the conceptual instrument to convert knowledge into wealth, improving citizens' quality of life. Both have centred their growth strategies on the concept of innovation, crucially tied to developments in the S\&T field. Both declare the will to harness innovation to increase citizens' inclusion and fight their respective poverties - material poverty in India and unemployment in EU. Through our reading, however, we have noticed prominent divergences in the understanding of who is an innovator, which stem from the particularities of the respective societies and contribute to different visions of the future.

In the European context, the RRI approach is currently gaining increasing relevance in the debate, representing the most promising arena where the issues of people's inclusion in decision-making on S\&T can develop. Such reflections, stemming from decade-long debates around the new production of scientific knowledge, scientific democracy and the embedding of social and ethical concerns in science policy agendas - although showing very diverse approaches and realizations - are opening confrontation spaces at the intersection of the academic and institutional arenas in EU. There is no analogous academically-led, advisory groups-based, debate in the Indian context, given the structural prominence that socially-aimed development paths have had since the independence in 1947 and the centrality of social justice in Indian innovation policy, even if ethical concerns about emerging technologies are appearing in India as well [Ladikas et al., 2015].

Innovation, for $\mathrm{EU}$, is the key target to regain growth and competitiveness, to overcome the economic crisis (the recent one and the long-term concerns about competitiveness) and to create new jobs for Europeans. The assumption here is that the increase of wealth will improve citizens' quality of life. The analysed documents mark also a stronger point: economic growth brought about by innovation represents the "only answer» to both economic and societal issues. Moreover, in many cases, discourses elaborate much more on the changes needed to boost innovation than on the complex paths to solve societal problems, as if implicitly assuming that increasing wealth (by means of technology) will automatically fix problems in the social, environmental or demographic fields.

It is possible to perceive here the subtle abiding tension between the idea of a full integration of the citizens in public deliberation on S\&T-related issues and the tendency to reducing their spaces, substituting their participation with inclusion via other means (e.g. tackling pre-established societal challenges or aligning R\&I with the values of society). The theories and experiences concerning citizens' inclusion in the European scenario are numerous and very diverse, spanning from serious attempts of involvement from the agenda-setting phase to more superficial practices where they are relegated to the roles of end-users or consumers.

Nonetheless, the analysed documents show that this ambiguity is not only due to incomplete practical realizations but descends also from an underlying tension, 
emerging from the discourses about innovation, between the demands of democracy and the temptation of technocracy. Against this landscape, the portrayal of citizens in research and innovation processes is often passive: they are principally asked to adapt to a changing world, and seldom they are described as adequate to be innovative knowledge producers themselves. In the EU discourses, "entrepreneurs" are the key actors of the European innovation system: they need to be supported and a «more positive European attitudes and culture towards entrepreneurship» should be fostered among the people and in the education sector [Aho et al., 2006, p. 1].

The Indian discourses on innovation, in contrast, are very much focused on the "people" instead of special sub-categories (like the European "entrepreneurs"). This peculiarity may stem from the radical demographic difference, in terms of number and age - India relying on more than double the population of Europe, with a high share of young people, with $34,8 \%$ of the population between the ages of 15 to 29 as of 2011 [Government of India Social Statistics Division, 2017]. The Indian documents are more positive towards the role of the public and envision people as active innovators because of its very young population, with strong growth prospects for the coming decades: optimism is what characterises the Indian documents. Europe, on the other hand, suffers from an aging population, which means that its understanding of the role of the people includes anxieties of getting the public involved in scientific decision making and in becoming active members in scientific debates. European discourses are consequently marked by the anxiety of decline.

The Indian approach is crucially focused on development objectives: eradication of poverty and harnessing of human resources. These stem from the needs of the society. Coherently, grassroots innovation holds a central place in the strategy, for its potential of inclusion of its diverse people (and their knowledge) and of representing an opportunity of development for the poorer sections. The inclusion of the people not just as users or collaborators of the innovative process, but as innovators/scientists themselves, is a key point of grassroots innovation. From the point of view of STS and science communication literature, this is also an interesting departure from the traditional deficit or dialogue models, both of which view science/scientists and the public as separate entities. With grassroots innovation, members of the public are accorded the position of an innovator - a producer in the innovation ecosystem. Within this framework, individual capability to do science and technology and to advance scientific knowledge is given high premium. The role of the government and the innovation think-tanks (working closely with the government) is to nurture individuals and traditional knowledge systems; and ensure that they are incorporated in the national ecosystem of innovation, alongside those organisations which are to provide infrastructural, institutional and financial support.

The comparative analysis of the discourses on innovation, the innovators and the people's role in the innovation process has shown, hence, how the same, globally shared, conceptual reference - the importance of innovation to contemporary knowledge-based economies - is subject to different understandings in the European and Indian cases, which are especially noteworthy because they question the very heart of democracies, i.e. citizens' involvement in deliberations - in this case regarding scientific policy. The acknowledgement of a heterogeneity in the 
political use of the innovation paradigm can help moving from an exclusively western perspective and suggesting diversities in the realization of innovation systems, connected to the contextual political objectives and the socio-cultural environment.

A deeper understanding of the discourses on innovation (and innovators) in the two contexts, moreover, can enlarge and refine the argumentative and metaphoric repertoire of science communicators. Furthermore, it can form the basis of a mature and shared debate on the role that knowledge production and innovation policies can and should play in the public governance of science and technology, in the definition of a scientific citizenship and in the enrichment of policy strategies regarding social justice at large.

In the following table, a selection of the most notable documents examined for both the political contexts.

Table 1: A selection of the most notable documents examined for both the political contexts.

\begin{tabular}{|c|c|c|}
\hline Author(s) & Title & Year \\
\hline $\begin{array}{l}\text { Commission of the } \\
\text { European } \\
\text { Communities (CEC) }\end{array}$ & Green Paper on Innovation & 1995 \\
\hline CEC & Towards a Europe of Knowledge & 1997 \\
\hline \multirow[t]{2}{*}{$\begin{array}{l}\text { Caracostas, P., \& } \\
\text { Muldur, U. }\end{array}$} & $\begin{array}{l}\text { Society, the endless frontier. A European Vision of Research and } \\
\text { Innovation Policies for the 21st Century. }\end{array}$ & 1998 \\
\hline & $\begin{array}{l}\text { Sorbonne Joint Declaration - "Joint declaration on harmonisation } \\
\text { of the architecture of the European higher education system" by the } \\
\text { four Ministers in charge for France, Germany, Italy and the United } \\
\text { Kingdom }\end{array}$ & 1998 \\
\hline $\begin{array}{l}\text { European Parliament } \\
\text { (EP) \& Council of } \\
\text { the European Union } \\
\text { (CEU) }\end{array}$ & $\begin{array}{l}\text { Dec. } N^{\circ} 1513 / 2002 / E C \text { of the European Parliament and of the } \\
\text { Council of } 27 \text { June } 2002 \text { concerning the sixth framework pro- } \\
\text { gramme of the European Community for research, technological } \\
\text { development and demonstration activities, contributing to the cre- } \\
\text { ation of the creation of the European Research Area and to innova- } \\
\text { tion (2002 to 2006). }\end{array}$ & 2002 \\
\hline CEC & $\begin{array}{l}\text { Innovation policy: updating the Union's approach in the context of } \\
\text { the Lisbon strategy }\end{array}$ & 2003 \\
\hline Sapir, A. et al. (2003) & $\begin{array}{l}\text { An Agenda for a Growing Europe- Making the EU Economic Sys- } \\
\text { tem Deliver, Report of an Independent High-Level Study Group } \\
\text { established on the initiative of the President of the European Com- } \\
\text { mission }\end{array}$ & 2003 \\
\hline Kok, W. et al. (2004) & $\begin{array}{l}\text { Facing the challenge - The Lisbon strategy for growth and employ- } \\
\text { ment, Report from the High Level Group chaired by Wim Kok }\end{array}$ & 2004 \\
\hline $\begin{array}{l}\text { Strauss-Kahn, D. } \\
\text { et al. }\end{array}$ & Building a Political Europe - 50 proposals for tomorrow's Europe & 2004 \\
\hline Muldur, U. et al. & $\begin{array}{l}\text { A New Deal for an Effective European Research Policy - The } \\
\text { Design and Impacts of the 7th Framework Programme }\end{array}$ & 2006 \\
\hline Aho, E., at al. & $\begin{array}{l}\text { Creating an Innovative Europe - Report of the Independent Expert } \\
\text { Group on RED and Innovation appointed following the Hampton } \\
\text { Court Summit and chaired by Mr. Esko Aho }\end{array}$ & 2006 \\
\hline EP \& CEU & $\begin{array}{l}\text { Decision No 1982/2006/EC of the European Parliament and of the } \\
\text { Council of } 18 \text { December } 2006 \text { concerning the Seventh Framework } \\
\text { Programme of the European Community for research, technological } \\
\text { development and demonstration activities (2007-2013). }\end{array}$ & 2006 \\
\hline
\end{tabular}


Table 1: Continued from the previous page.

\begin{tabular}{|c|c|c|}
\hline Author(s) & Title & Year \\
\hline CEC & $\begin{array}{l}\text { Inventing our future together. The European Research Area: New } \\
\text { Perspectives - Green Paper }\end{array}$ & 2007 \\
\hline Wynne, B. et al. & $\begin{array}{l}\text { Taking European Knowledge Society Seriously. Report of the Ex- } \\
\text { pert Group on Science and Governance to the Science, Economy and } \\
\text { Society Directorate, Directorate-General for Research, European } \\
\text { Commission }\end{array}$ & 2007 \\
\hline \multirow[t]{2}{*}{ Georghiou, L. et al. } & $\begin{array}{l}\text { Challenging Europe's Research: Rationales for the European Re- } \\
\text { search Area (ERA) - Report of the ERA Expert Group }\end{array}$ & 2008 \\
\hline & $\begin{array}{l}\text { New worlds, new solutions - research and innovation as a basis } \\
\text { for developing Europe in a global context - (including "the Lund } \\
\text { Declaration") }\end{array}$ & 2009 \\
\hline $\begin{array}{l}\text { European } \\
\text { Commission (EC) }\end{array}$ & $\begin{array}{l}\text { Europe } 2020-A \text { strategy for smart, sustainable and inclusive } \\
\text { growth }\end{array}$ & 2010 \\
\hline EC & Europe 2020 Flagship Initiative Innovation Union & 2010 \\
\hline $\mathrm{EC}$ & $\begin{array}{l}\text { Horizon } 2020 \text { - The Framework Programme for Research and In- } \\
\text { novation }\end{array}$ & 2011 \\
\hline EC & $\begin{array}{l}\text { Responsible Research and Innovation - Europe's ability to respond } \\
\text { to societal challenges — leaflet }\end{array}$ & 2012 \\
\hline EP \& CEU & $\begin{array}{l}\text { Regulation (EU) No 1291/2013 of the European Parliament and of } \\
\text { the Council of } 11 \text { December } 2013 \text { establishing Horizon 2020 - the } \\
\text { Framework Programme for Research and Innovation (2014-2020) } \\
\text { and repealing Decision No 1982/2006/EC }\end{array}$ & 2013 \\
\hline $\begin{array}{l}\text { van den Hoven, J. } \\
\text { (chair) et al. }\end{array}$ & $\begin{array}{l}\text { Options for Strengthening Responsible Research and Innovation- } \\
\text { Report of the Expert Group on the State of Art in Europe on Re- } \\
\text { sponsible Research and Innovation }\end{array}$ & 2013 \\
\hline Ramasami, T. & Nurturing Centers of Excellence & 2011 \\
\hline $\begin{array}{l}\text { Ministry of Science } \\
\text { and Technology, } \\
\text { Government of India }\end{array}$ & Science, Technology and Innovation Policy (STI) 2013 & 2013 \\
\hline $\begin{array}{l}\text { National Innovation } \\
\text { Council }\end{array}$ & Report to the People & 2013 \\
\hline $\begin{array}{l}\text { National Innovation } \\
\text { Foundation }\end{array}$ & Annual Report & 2015 \\
\hline Krishna, V. V. & Policy brief: Science, Technology and Innovation policy in India & 2016 \\
\hline $\begin{array}{l}\text { Srinivas, KR, Kumar, } \\
\text { A, \& Pandey, N. }\end{array}$ & $\begin{array}{l}\text { Responsible Research and Innovation in Practice: Report from na- } \\
\text { tional case study - India }\end{array}$ & 2018 \\
\hline
\end{tabular}

References
Abraham, I. (2006). 'The contradictory spaces of postcolonial techno-science'. Economic and Political Weekly 41 (3), pp. 210-217.

URL: https : //www . jstor org/stable/4417699.

Aho, E., Cornu, J., Georghiou, L. and Subirá, A. (2006). Creating an innovative europe. Report of the Independent Expert Group on R\&D and Innovation appointed following the Hampton Court Summit and chaired by Mr. Esko Aho. Brussels, Belgium.

Andrée, D. (2009). Priority-setting in the European research framework programmes. URL: https : //www . vinnova.se/contentassets/7731e8676b274f408d932161a6 e8e381/va-09-17.pdf.

Basile, E. and Réigner, P. (2012). Review of the SET cooperation agreement between the European Union and the government of the Republic of India 2007-2011. Brussels, Belgium. URL: https://ec .europa.eu/research/iscp/pdf/policy/india-rev iew-brochure.pdf. 
Borrás, S. (2000). Science, technology and innovation in European Politics. Research paper 5/00 from the department of social sciences. Roskilde, Denmark: Roskilde University.

Bowen, G. A. (2009). 'Document analysis as a qualitative research method'. Qualitative Research Journal 9 (2), pp. 27-40. https://doi.org/10.3316/qrj0902027.

Caracostas, P. and Muldur, U. (1998). Society, the endless frontier. A European Vision of research and innovation policies for the 21st century. Luxembourg.

Cerroni, A. and Giuffredi, R. (2015). 'L'orizzonte di Horizon 2020: il futuro europeo nelle politiche della ricerca'. Futuri 6, pp. 31-41.

URL: https://www futurimagazine.it/dossier/politiche-per-il-futuro/h orizon-2020-il-futuro-europeo-nelle-politiche-della-ricerca/.

Commission of the European Communities (1995). Green paper on innovation. COM (95) 688 final. Brussels, Belgium.

- (1997). Towards a Europe of knowledge. COM (97) 563 final. Brussels, Belgium.

- (2003). Innovation policy: updating the union's approach in the context of the Lisbon strategy. COM (2003) 112 final. Brussels, Belgium.

- (2007). Inventing our future together. The European Research area: new perspectives green paper. COM (2007) 161. Brussels, Belgium.

Davies, S., McCallie, E., Simonsson, E., Lehr, J. L. and Duensing, S. (2009). 'Discussing dialogue: perspectives on the value of science dialogue events that do not inform policy'. Public Understanding of Science 18 (3), pp. 338-353. https://doi.org/10.1177/0963662507079760.

Dodds, A. (2012). Comparative public policy. New York, NY, U.S.A.: Palgrave Macmillan.

EC, EACEA and Eurydice (2016). Entrepreneurship education at school in Europe. Eurydice report - 2016 edition. Brussels, Belgium.

European Commission (2010a). Europe 2020 - a strategy for smart, sustainable and inclusive growth. COM (2010) 2020 final. Brussels, Belgium.

- (2010b). Europe 2020 flagship initiative innovation union. COM (2010) 546 final. Brussels, Belgium.

- (2011). Horizon 2020 - the framework programme for research and innovation. COM (2011) 808 final. Brussels, Belgium.

- (2012). Responsible research and innovation - Europe's ability to respond to societal challenges. Leaflet. Brussels, Belgium.

- (2014). Responsible research E innovation. Brussels, Belgium.

URL: https://ec . europa. eu/programmes/horizon2020/en/h2020-section/re sponsible-research-innovation.

- (2015). Responsible research and innovation: aligning REI with European society. [YouTube video]. URL: https : / /www . youtube. com/watch?v=bs5A-4j5h-I.

European Parliament and Council of the European Union (2002). Decision No 1513/2002/EC of the European Parliament and of the Council of 27 June 2002 concerning the sixth framework programme of the European Community for research, technological development and demonstration activities, contributing to the creation of the European Research Area and to innovation (2002 to 2006). Brussels, Belgium. URL: https://eur-lex.europa.eu/eli/dec/2002/1513/oj.

- (2006). Decision No 1982/2006/EC of the European Parliament and of the Council of 18 December 2006 concerning the Seventh Framework Programme of the European Community for research, technological development and demonstration activities (2007-2013). Brussels, Belgium. URL: https://eur-lex. europa.eu/legal-cont ent/EN/TXT/?uri=CELEX\%3A32006D1982. 
European Parliament and Council of the European Union (2013). Regulation (EU) No 1291/2013 of the European Parliament and of the Council of 11 December 2013 establishing Horizon 2020 - the Framework Programme for Research and Innovation (2014-2020) and repealing Decision No 1982/2006/EC Text with EEA relevance. Brussels, Belgium. URL: https://eur-lex.europa.eu/legal-content/EN/TXT /?uri=CELEX\%3A32013R1291.

Felt, U., Fochler, M. and Winkler, P. (2010). 'Coming to terms with biomedical technologies in different technopolitical cultures: a comparative analysis of focus groups on organ transplantation and genetic testing in Austria, France and the Netherlands'. Science, Technology, \& Human Values 35 (4), pp. 525-553. https://doi.org/10.1177/0162243909345839.

Fischer, F. and Forester, J., eds. (1993). The argumentative turn in policy analysis and planning. Durham, NC, U.S.A.: Duke University Press.

Fischer, F. and Gottweis, H. (2012). 'Introduction: the argumentative turn revisited'. In: The argumentative turn revisited. Durham, NC, U.S.A.: Duke University Press, pp. 1-27.

Gaskell, G. (2000). 'Individual and group interviewing'. In: Qualitative researching with text, image and sound. Ed. by M. Bauer and G. Gaskell. London, U.K.: Sage, pp. 38-56.

Georghiou, L. et al. (2008). Challenging Europe's research: rationales for the European Research Area (ERA). Report of the ERA expert group. Brussels, Belgium.

Giuffredi, R. (2016). ‘La transizione dall' «Europa della conoscenza» all'«Unione dell'innovazione» nella politica della ricerca europea'. PHYSIS Rivista Internazionale di Storia della Scienza LI (1-2), pp. 187-200.

Godin, B. (2009). The making of science, technology and innovation policy: conceptual frameworks as narratives, 1945-2005. Montreal, QC, Canada: Institut national de la recherche scientifique. URL: http://www.csiic.ca/PDF/TheMakingOfScience.pdf.

Goven, J. (2006). ‘Processes of inclusion, cultures of calculation, structures of power: scientific citizenship and the royal commission on genetic modification'. Science, Technology, \& Human Values 31 (5), pp. 565-598. https://doi.org/10.1177/0162243906289612.

Government of India Social Statistics Division (2017). Youth in India. URL: http://mospi.nic.in/sites/default/files/publication_reports/You th_in_India-2017.pdf.

Gupta, A. K. (2013). Tapping the entrepreneurial potential of grassroots innovation. Stanford Social Innovation Review. URL: http://ssir.org/articles/entry/ta pping_the_entrepreneurial_potential_of_grassroots_innovation.

- (2016). Grassroots innovation: minds on the margin are not marginal minds. New Delhi, India: Random House Publishers India Pvt. Limited.

Guzzetti, L. (1995). A brief history of European union research policy.

Heidenheimer, A. J., Heclo, H. and Adams, C. T. (1975). Comparative public policy: the politics of social choice in America, Europe and Japan. New York, NY, U.S.A.: St. Martin's Press.

House of Lords (2000). Third Report: Science and Society. London, U.K.: The Stationery Office.

Irwin, A. and Wynne, B. (1996). Misunderstanding Science? The Public Reconstruction of Science and Technology. Cambridge, U.K.: Cambridge University Press. https://doi .org/10.1017/cbo9780511563737.

Irwin, A. (2014). 'From deficit to democracy (re-visited)'. Public Understanding of Science 23 (1), pp. 71-76. https://doi.org/10.1177/0963662513510646. 
Jasanoff, S. (2005). Designs on Nature. Princeton, U.S.A.: Princeton University Press.

Jasanoff, S. and Kim, S.-H. (2015). Dreamscapes of Modernity: Sociotechnical Imaginaries and the Fabrication of Power. Chicago, U.S.A.: The University of Chicago Press.

Jayaraman, T. (2009). 'Science, technology and innovation policy in India under economic reform: a survey'. In: International conference on "the crisis of neo-liberalism in India: challenges and alternatives" (Tata Institute of Social Sciences (TISS), Mumbai, India, 13th-15th March 2009). International Development Economics Associates (IDEAs).

URL: http://www. networkideas.org/ideasact/jan09/PDF/Jayaraman.pdf.

Kok, W. et al. (2004). Facing the challenge - the Lisbon strategy for growth and employment. Report from the high level group chaired by Wim Kok. Brussels, Belgium.

Krishna, V. V. (2016). Policy brief: science, technology and innovation policy in India. Vienna, Austria: Centre for Social Innovation (ZSI).

URL: http://www.zsi.at.

Ladikas, M., Chaturvedi, S., Zhao, Y. and Stemerding, D., eds. (2015). Science and technology governance and ethics: a global perspective from Europe, India and China. Cham, Switzerland: Springer International Publishing. https://doi.org/10.1007/978-3-319-14693-5.

Merriam, S. B. (1988). Case study research in education: a qualitative approach. San Francisco, CA, U.S.A.: Jossey-Bass.

Ministry of Science and Technology, Government of India (2013). Science, technology and innovation policy (STI) 2013. URL: http://www. dst.gov. in/sites/default /files/STI\%20Policy\%202013-English.pdf.

Muldur, U., Corvers, F., Delanghe, H., Dratwa, J., Heimberger, D., Sloan, B. and Vanslembrouck, S. (2006). A new deal for an effective European research policy - the design and impacts of the 7th framework programme. Dordrecht, Netherlands: Springer. https://doi .org/10.1007/978-1-4020-5551-5.

National Innovation Foundation (2015). Annual report. New Delhi, India.

Nowotny, H. (2014). 'Engaging with the political imaginaries of science: near misses and future targets'. Public Understanding of Science 23 (1), pp. 16-20. https://doi.org/10.1177/0963662513476220.

OECD (1963). The measurement of scientific and technical activities - proposed standard practice for surveys of research and development. (Frascati manual, 1st edition). URL: http://www .oecd.org/sti/inno/Frascati-1963.pdf.

- (1993). The measurement of scientific and technical activities - proposed standard practice for surveys of research and development. (Frascati manual, 5th edition). https://doi.org/10.1787/9789264063525-en.

- (2014). India policy brief: innovation. OECD better policies series. URL: https://www .oecd.org/policy-briefs/India-Addressing-Economic-an d-Social-Challenges-through-Innovation.pdf.

- (2015). The measurement of scientific and technical activities - guidelines for collecting and reporting data on research and development. (Frascati manual, 6th edition). Paris, France. https://doi .org/10.1787/9789264239012-en.

OECD and Eurostat (1996). Oslo manual - the measurement of scientific and technological activities - proposed guidelines for collecting and interpreting technological innovation data.

- (2005). Oslo manual - the measurement of scientific and technological activities guidelines for collecting and interpreting innovation data. 
Owen, R. (2014). Responsible research and innovation: options for research and innovation policy in the EU. Brussels, Belgium.

URL: https://ec .europa.eu/research/innovation-union/pdf/expert-group s/Responsible_Research_and_Innovation.pdf.

Owen, R., Macnaghten, P. and Stilgoe, J. (2012). 'Responsible research and innovation: From science in society to science for society, with society'. Science and Public Policy 39 (6), pp. 751-760. https://doi.org/10.1093/scipol/scs093.

Owen, R., Stilgoe, J., Macnaghten, P., Gorman, M., Fisher, E. and Guston, D. (2013). 'A framework for responsible innovation'. In: Responsible innovation: managing the responsible emergence of science and innovation in society. Chichester, U.K.: John Wiley \& Sons, pp. 27-50.

Pfotenhauer, S. and Jasanoff, S. (2017). 'Panacea or diagnosis? Imaginaries of innovation and the 'MIT model' in three political cultures'. Social Studies of Science 47 (6), pp. 783-810. https : //doi.org/10.1177/0306312717706110.

Planning commission (2001). Indian planning experience - a statistical profile. New Delhi, India. URL: http://planningcommission.nic.in.

Ramasami, T. (2011). Nurturing centers of excellence. URL: https://www . jsps . go . jp /english/asiahorcs/data/meetings/5th/special_lec.pdf.

RRI tools (2014). RRI tools homepage. URL: http://www.rri-tools . eu/.

Sanz Menéndez, L. and Borrás, S. (2000). Explaining changes and continuity in EU technology policy: the politics of ideas. Madrid, Spain. URL: http://hdl . handle. net/10261/1490.

Sapir, A. et al. (2003). An agenda for a growing Europe - making the EU economic system deliver. Report of an independent high-level study group established on the initiative of the president of the European commission. Brussels, Belgium.

Schibeci, R. and Harwood, J. (2007). 'Stimulating authentic community involvement in biotechnology policy in Australia'. Public Understanding of Science 16 (2), pp. 245-255. https://doi.org/10.1177/0963662506067909.

Schön, D. A. and Rein, M. (1994). Frame reflection: Toward the resolution of intractable policy controversies. New York, NY, U.S.A.: Basic Books.

Sorbonne Declaration (1998). Sorbonne Joint Declaration - "Joint declaration on harmonisation of the architecture of the European higher education system" by the four Ministers in charge for France, Germany, Italy and the United Kingdom. Paris, France.

Srinivas, K. R., Kumar, A. and Pandey, N. (2018). Responsible research and innovation in practice: report from national case study - India.

URL: https://www.rri-practice.eu/wp-content/uploads/2018/09/RRI-Prac tice_National_Case_Study_Report_INDIA.pdf.

Stilgoe, J., Owen, R. and Macnaghten, P. (2013). ‘Developing a framework for responsible innovation'. Research Policy 42 (9), pp. 1568-1580. https://doi.org/10.1016/j.respol.2013.05.008.

Stirling, A. (2006). From science and society to science in society: towards a framework for "co-operative research". Report of the European commission Gover' science 2005 workshop. Brussels, Belgium.

Strauss-Kahn, D. et al. (2004). Building a political Europe - 50 proposals for tomorrow's Europe. Brussels, Belgium.

Sutcliffe, H. (2011). A Report on Responsible Research and Innovation. Prepared for DG Research. European Commission.

URL: http://ec.europa.eu/research/science-society/document_library/p df_06/rri-report-hilary-sutcliffe_en.pdf. 
The Lund Declaration (2009). New worlds, new solutions - research and innovation as a basis for developing Europe in a global context - (including "the Lund Declaration"). Lund, Sweden. URL: https://era.gv . at/object/document/130 /attach/1lund_declaration_final_version_9_july.pdf.

Ulnicane, I. (2016). "'Grand challenges" concept: a return of the "big ideas" in science, technology and innovation policy?' International Journal of Foresight and Innovation Policy $11(1 / 2 / 3)$, p. 5. https://doi.org/10.1504/ijfip.2016.078378.

van den Hoven, J. (chair) et al. (2013). Options for strengthening responsible research and innovation. Report of the expert group on the state of art in Europe on responsible research and innovation. Brussels, Belgium.

Von Schomberg, R. (2013). 'A Vision of Responsible Research and Innovation'. In: Responsible Innovation. Ed. by R. Owen, J. Bessant and M. Heintz. New York, NY, U.S.A.: John Wiley \& Sons, Ltd, pp. 51-74. https://doi.org/10.1002/9781118551424.ch3.

Wilder, M. (2017). 'Comparative public policy: origins, themes, new directions'. Policy Studies Journal 45 (S1), S47-S66. https : //doi . org/10.1111/ps j. 12200.

Wynne, B. et al. (2007). Taking European knowledge society seriously. Report of the expert group on science and governance to the science, economy and society directorate. Brussels, Belgium.

Authors

Anwesha Chakraborty is a Postdoctoral researcher at Department of Technology Management and Economics, Chalmers University of Technology, Gothenburg. E-mail: anwesha@chalmers.se.

Rita Giuffredi is a Postdoctoral researcher ("Assegnista di ricerca") at IREA-CNR, Milan, working on the communication and coordination of the European initiative BlueMed and researching on science policy, communication and democracy.

E-mail: giuffredi.r@irea.cnr.it.

\section{How to cite}

Chakraborty, A. and Giuffredi, R. (2019). 'Science and technology for the people? On the framing of innovation in policy discourses in India and in EU'. JCOM 18 (03), A05. https:/ / doi.org/10.22323/2.18030205. 